\title{
ÖZ DÜZENLEMEYE DAYALI ÖĞRENME VE YAZMA EĞİTİMI
}

\section{Murat ÖZBAY*}

Tuğçe DAŞÖZ ${ }^{* *}$

\begin{abstract}
$\ddot{O} \mathbf{z}$
Öğrencilerin kendi öğrenme süreçlerine etkin katılma derecesiyle ilgili bir kavram olan öz düzenlemeye dayalı ögrenme, bir amaca ulaşmak için üretilen düşünce, duygu ve eylemler olarak tarif edilmektedir. Öz düzenlemeye dayalı öğrenmede insanın aktif katılımı gerekmektedir. Bu süreçte dil de anahtar rol üstlenmektedir. Bu sebeple eğitim sürecinde dil öğretimi önemli bir yer tutmaktadır. Eğitim süresince gelișen dil becerilerinden biri de yazmadır. İnsan kendini ifade etmek için konuşmanın yanı sıra yazmadan da yararlanır. Yazma, insanın konuşmadan sonra en çok kullandığı iletişim aracıdır. İnsan yazı yazarken, sahip olduğu duygu ve düșünceleri belirli bir bilgi birikimi çerçevesinde düzenleyip aktarmaktadır. Yazma, bilinçli bir çaba ile bireyin bilerek çözümleyici bir eyleme girişmesini gerektirir. Bu bilinçli ve çözümleyici zihinsel çaba sebebiyle yazmada kullanılan zihinsel işlemler öz düzenleme kavramı içerisine girer. Yazılı anlatım; bu açıdan bakıldığında kişinin bilgisi, konuyu kavrama düzeyi, sunmadaki düzeni, amacı ve konu hakkındaki fikirlerini yazıya dökmek için gerçekleştirdiği zihinsel faaliyettir. Çocuğun yazma becerileri geliştikçe bilgiyi transfer etme, düşünceleri gözden geçirip düzenleme daha etkili bir șekilde yapılır. Bu durum daha üst düzey yazılı ürünlerin ortaya çıkmasını sağlar. İşte uzun bir süreç isteyen yazma eğitiminin amaçlarına ulaşılmasında öz düzenlemeye dayalı ögrenmenin önemli bir yeri vardır.
\end{abstract}

Anahtar Sözcükler: Öz düzenlemeye dayalı öğrenme, eğitim, yazma, yazma eğitimi.

\section{SELF-REGULATED LEARNING AND WRITING INSTRUCTION}

\begin{abstract}
Self-regulated learning, as a concept related to degree of active participation of students in their own learning process, can be defined as thoughts, feelings and emotions produced for attaining a goal. In the self-regulated learning active participation of people is required. In this process language plays a key role. Because of that, language instruction has an important place in the educational processes. One of the developing language skills through education is writing. People use writing as well as speaking to express themselves. Writing is the most widely used communication skill after speaking. While writing something, people transfer their own feelings and thoughts by organizing within a framework shaped by knowledge. Because of these conscious and analytic effort, mental processes used in writing process included in selfregulation concept. When viewed from this angle, writing is the sum of individual's aim, knowledge, level of comprehension of the subject, organization of presentation, and mental activities carried out to to write down the ideas on subject. Transferring knowledge, editing and revising ideas is done
\end{abstract}

\footnotetext{
* Prof. Dr.; Gazi Üniversitesi Gazi Eğitim Fakültesi Türkçe Eğitimi Bölümü, mozbay@ gazi.edu.tr.

** Arş. Gör.; Gazi Üniversitesi Gazi Eğitim Fakültesi Türkçe Eğitimi Bölümü, tugcedasoz@ gmail.com.
} 
in a more effective way while children's' writing skills develop. This development makes the emergence of high level written products. Selfregulated learning has an important role in achieving the objectives of writing instruction, which takes a long time.

Keywords: Self-regulated learning, education, writing, writing instruction.

\section{Giriş}

Araştırmacılar tarafindan öz düzenlemeye dayalı öğrenme kavramı 1980'li yıllarda yoğun olarak kullanılmaya başlanmış olmakla beraber bunun öğrenme üzerindeki etkilerinin araştırılmaya başlanması 1960'lı yıllara kadar gider. $\mathrm{Bu}$ araştırmalar kendi içinde gruplandırıldığında bazı araştırmacıların strateji öğretimine odaklandığı, bazı araştırmacıların ise öz düzenlemeye dayalı öğrenme içinde motivasyonun rolü üzerine yoğunlaştığ 1 görülmektedir (Uyar, 2015, s. 45). Bu çalışmalar içerisinde dil eğitimiyle ilgili olanlar da bulunmaktadır. İnsanlar arasında iletişimi sağlayan temel öge dil olduğu için eğitim sürecinde dil öğretimi önemli bir yer tutmaktadır. Dil eğitimi süresince gelişen dil becerilerinden (konuşma, okuma, dinleme, yazma, görsel okuma ve görsel sunu) biri de yazmadır. Coşkun (2007a, s. 49), bu becerilerin geliştirilmesinin gerek ana dili gerekse yabancı dil eğitiminin temel hedefleri arasında olduğunu vurgulamaktadır.

İnsan anlatma ihtiyacı için "konuşma ve yazma" olmak üzere iki temel beceriden yararlanır. İnsanın konuşmadan sonra en çok kullandığı anlatma becerisi ise yazmadır. Yazma, herhangi bir bilginin, görüşün kalıcılığını sağlayan, nesiller hakkında bize bilgi veren bir iletişim aracıdır. İnsanoğlu da yazıyı konuşmadan çok sonra öğrendiği hâlde bizler o günlere ait bilgileri yine yazı sayesinde öğrenmekteyiz (Beyreli, Çetindağ ve Celepoğlu, 2005, s. 36). "İnsanlar, duygu, düşünce, istek ve tasarımların, hayallerini başkalarına aktarmak, uzaktakilere duyurmak, gelecek nesillere ulaştırmak isterler ve bunun için de yazıya başvururlar" (Özbay, 2002, s. 173). Yazı; insanın istek, duygu, görüş ve düşüncelerini taş, kumaş, ağaç, tahta, kâğıt, ekran vb. üzerine çeşitli sembollerle aktarmasıdır.

\section{Öz Düzenlemeye Dayalı Öğrenme}

“Öz düzenleme” kavramı Türkçe Sözlük’te bulunmamaktadır. Sözlük, “düzenleme” kelimesi için ise "Düzenlemek işi, tertip, organizasyon" karşıllklarını vermektedir (http://www.tdk.gov.tr/). Eğitim literatüründe görülen öz düzenleme kavramının çeşitli bakış açılarına göre birçok tanımı bulunmaktadır. Bandura, öz düzenlemeye sosyal biliş kuramı çerçevesinden yaklaşırken, bireylerin, düşünceleri, hisleri ve hareketleri üzerinde kontrol 
kurabildikleri bir iç sisteme sahip olduklarını belirtir. Bu iç sistem kişinin sembolleştirme becerisini, başkalarından öğrenmesini, alternatif stratejiler planlamasını, kendi davranışlarını düzenlemesini de içeren bilişsel ve duyuşsal yapısı üzerine kurulmuştur. İç sistem bireylere çevrelerini değiştirme ve kendi hareketlerini etkileme yeterliliği sağlayarak öz düzenleyici bir işlev görür (Pajares, 1996, s. 543). Bandura'ya göre birey, öz değerlendirme sonucunda kendini içsel olarak pekiştirir. Davranışın düzenlenmesinde, içten gelen pekiştirmeler başkalarından alınan pekiştirmelerden daha etkilidir (Senemoğlu, 2009, s. 232).

İsrael'e göre (2007, s. 3), öz düzenlemeye daha davranışsal bir bakış açısıyla yaklaşan Tice ve Bratlavasky öz düzenleme terimini bireyin, belirli bir amaç doğrultusunda, tepkileri ile önemli dürtülerini değiştirmek ve bunların yerine başka tepkileri koymak için gösterdiği herhangi bir çabayı belirtmek için kullanırlar (Tice ve Bratslavasky'den aktaran Luszczynska, Diehl, Gutierrez-Dona, Kuusinen, Schwarzer, 2004, s. 556). Buna göre öz düzenlemeye dayalı öğrenmede önemli olan nokta amaçtır. Bireyin, konunun amacına göre duygu ve düşüncelerini düzenlemesi ile bir metin ortaya çıkabilir.

Öğrencilerin kendi öğrenme süreçlerine etkin katılma derecesiyle ilgili bir kavram olarak karşımıza çıkan öz düzenlemeye dayalı öğrenme, bir akademik hedefe ulaşmak için üretilen düşünce, duygu ve eylemler olarak tanımlanmaktadır (Zimmerman, 2000). Bir anlamda öz düzenleme, bireyin kendi öğrenme sürecinin sorumluluğunu alması ve onu aktif olarak kontrol etmesidir. Öz düzenlemeli öğrenme modellerine göre öğrenciler biliş yapılarını, güdülerini ve çevresel etmenleri göz önüne alarak kendi öğrenme hedeflerini belirler, bu hedeflere ulaşmak için öz düzenleme yaparlar (Pintrich, 2004).

Bu tanımlara göre öz düzenlemeye dayalı öğrenmede bireyin aktif katılımı gerekmektedir, ancak bu katılım davranışsal boyutun yanında, bilişüstü ve güdüsel boyutta da gerçekleşmelidir. Örneğin yazı yazmak için uzun süre çalışmak davranışsal boyutta bir katılıma işaret ederken, gerekli güdü ve bilişüstü stratejiler olmadan verimli bir yazma süreci gerçekleştirilemez. Bu durumda birey "Ben elimden geleni yapıyorum. Yazmak için çok zaman harcayarak çabalıyorum.” diyerek kendini rahatlatsa da bilişüstü ve güdüsel stratejilerin kullanımını göz ardı ederek yazma sürecini olumsuz yönde etkilemektedir.

Schunk (1994'ten akt. İsrael, 2007, s. 4), öz düzenlemeyi yapılan etkinlikler açısından değerlendirmiştir. Ona göre öz düzenleme kişinin; öğretime dikkat etmesini ve konsantre olmasını, hatırlanacak olan bilgiyi örgütlemesini, kodlama yapması ve tekrarlamasını, verimli bir 
çalışma ortamı yaratmasını, kaynakları etkili kullanmasını; yeterlikleri, öğrenmenin değeri, öğrenmeyi etkileyen etmenler, beklenen eylemlerin çıktıları hakkında pozitif inançlara sahip olmasını, çabası ile övünç ve mutluluk duymasını içeren etkinlikleri kapsar.

$\mathrm{Bu}$ doğrultuda öz düzenleme, bireyin kendi öğrenme sürecinin sorumluluğunu almas1, bunu planlaması ve kontrol etmesi olarak düşünülebilir (Aydın ve Atalay, 2015, s. 3).

Öz düzenlemeye dayalı öğrenmenin tanımlarına bakıldığında alanda en çok bilinen tanımın Schunk ve Zimmerman (1994) tarafından yapıldığı anlaşılmaktadır. Buna göre öz düzenlemeye dayalı öğrenme "bireyin kendi kendine ürettiği düşünce, duygu ve davranışları sistematik bir şekilde belirli bir hedefe ulaşmaya yönelik olarak kullanması" (Schunk ve Zimmeran, 1994, s. IX) şeklinde ifade edilmektedir. Bu tanımdan yola çıkarak Boekearts (2002, 595) öz düzenlemeye dayalı öğrenmeyi "öğrencinin mevcut koşulları da dikkate alarak, kişisel hedeflerine ulaşmak için kendi kendine ürettiği düşünce, duygu ve davranışları sistematik olarak kullandığ 1 bir girişim”, Pintrich ise "öğrenenin hedefler belirlediği; bilişsel durumunu, motivasyonunu ve davranışlarını izlemeye, düzenlemeye ve kontrol etmeye çalıştığ1; belirlenen hedefler ve bağlamın özellikleri tarafından yönlendirilen ve sınırlandırılan aktif ve yapılandırmacı bir süreç" (2000b, s. 453) olarak tanımlamaktadır.

Zimmerman (1989) hem üst bilişsel hem motivasyonel hem de davranışsal olarak kendi öğrenme süreçlerinin aktif katılımcısı olan öğrencilerin öz düzenleme becerilerinin geliştiğinin söylenebileceğini dile getirmekte ve bu tür öğrencilerin ebeveyn ya da öğretmen gibi herhangi bir yetişkine bağlı kalmak yerine, belirli bir hedefe ulaşmak için kendilerinin harekete geçtiklerini ve çalışmalarını kendilerinin yönettiğini belirtmektedir. Nitekim Perry (1998) de öz düzenleme teriminin üst bilişsel farkındalığı olan, içsel olarak motive olmuş ve stratejik hareket eden öğrenciler için kullanılabileceğini ifade etmektedir.

Burada kullanılan üst bilişsel farkındalık, içsel olarak motive olma ve stratejik hareket etme kavramları ile nelerin anlatılmak istendiği şu şekilde açıklanmaktadır: Öz düzenlemeye dayalı öğrenme becerileri gelişmiş öğrenciler karşılaştıkları zor görevlerin gerekliliklerinin ve kendi becerilerinin bu gereklilikleri karşılama düzeyinin (kendi zayıf ve güçlü yanlarının) ve zorlu bir görevin üstesinden gelmek için hangi stratejileri kullanabileceklerinin farkındadırlar, yani üst bilişsel farkındalıkları gelişmiştir. Ayrıca bu öğrenciler becerilerinin gelişebileceğine inanırlar, kendi kişisel gelişimlerine ve öğrenme düzeylerine odaklanırlar, becerilerinin gelişmesine önem verdikleri için onları geliştirecek zorlu görevlere katılmaya karşı isteklidirler, 
yüksek düzeyde öz yeterlilik algısına sahiptirler, çalışmalarının sonuçlarını kontrol edebildikleri değişkenlere atfederler, yani motivasyonları yüksektir. Son olarak da zorlu bir görevlerle karşılaştıkları zaman, bu görevin üstesinden gelmek için stratejilerle ilgili bilgi ve birikimlerinden hareketle en uygun olduğunu düşündükleri stratejiyi seçerler ve uygularlar, yani stratejik davranırlar (Perry ve Drummond, 2002; Perry, Nordby ve VandeKamp, 2003; Perry, Philips ve Hutchinson, 2006'dan akt. Uyar, 2015, s. 46).

Zimmerman (2001'den akt. Güvenç, 2010, s. 1463), öz düzenlemeye dayalı öğrenmeyi “edim öncesi hazırlık", “edim” ve "edim sonrası” olarak üç evreyle açıklamaktadır. Bu modele göre öz düzenlemeye dayalı öğrenmenin başlangıç aşaması olan edim öncesi hazırlık evresinde, öğrenci hem uygun öğrenme stratejilerini belirlemekte hem de kendini bu stratejileri kullanmaya hazırlamaktadır. Edim evresinde ise öğrenme stratejisini belirleyen, güdüsel olarak kurulan öğrenci stratejik planını uygulamaya koymakta, hem çevresini yapılandırmakta hem de zamanını denemektedir. Öğrenmenin gerçekleştiği edim evresini en az onun kadar önemli olan edim sonrası evresi izlemektedir. $\mathrm{Bu}$ evrede ilk iki evre ile ilgili yansıtmalar yapılmakta, öğretimsel iş sonucu elde edilen ürün, süreç sırasındaki çaba, elde edilen doyum gözden geçirilmektedir.

Zimmerman'ın öğrenme sürecini hedef alan tanımına göre yazma süreci şu şekilde basamaklara bölünebilir: Edim öncesi hazırlık evresinde yazma sürecine hazırlık ve yazma taslağı oluşturma aşamaları bulunabilir. Edim evresinde, gözden geçirme, geliştirme ve düzenleme aşamaları; edim sonrasında ise düzeltme, yayma ve paylaşma aşamaları yer alabilir.

\section{Öz Düzenlemenin Süreçleri}

Klasik sosyal bilişsel bakış açısı öz düzenlemenin, gözlemleme(izleme), yargılama ve tepki olmak üzere üç süreçten oluştuğunu iddia eder.

Tablo 1: Öz Düzenlemenin Süreçleri

\begin{tabular}{ccc}
\hline Gözlemleme & Değerlendirme & Tepki \\
\hline Düzenlilik & Standart türleri & Değerlendiren motive ediciler \\
\hline Yakınlık & Hedef özellikleri & Somut motive ediciler \\
\hline Öz kayıt & Hedefin önemi & \\
\hline & Nitelikler & \\
\hline
\end{tabular}


Gözlemleme: Davranışlarını standartlara göre değerlendirmeyi ve buna göre olumlu veya olumsuz tepki vermeyi içerir. Bireylerin değerlendirmeleri ve tepkileri daha sonraki aynı veya farklı davranış yönlerini gözlemlemede temel oluşturmaktadır. Bu süreçler çevreden bağımsız değildir. Öğrenme süreçlerini yetersiz gören öğrenciler öğretmenden yardım isteyerek tepki gösterebilirler ki bu da çevrelerini etkilemiş olur. Aynı zamanda öğretmen de öğrencilerinin sonradan kendi öğrenmelerini geliştirmede kullanacakları daha etkili bir strateji anlatabilir. Bu tür çevresel etkiler öz düzenlemeyi geliştirmeye yardım eder ve bu da öğrencilere öz düzenleme becerilerinin öğretebileceğini göstermesi bakımından önemlidir (Schunk ve Zimmerman, 1994, 1998’ten akt. Schunk, 2009, s. 117-118).

Değerlendirme: Bireyin performansı ile hedefine ulaşmadaki başarısını karşı1laştırmak anlamındadır. Kazanılan değerlendirme, standartlara, hedef özelliklerine, hedefin önemine ve niteliklerine bağlıdır.

Değerlendirme standartları kesin veya normatif olabilir. Kesin standartlar sabit olabilir ancak normatif standartlar bireylerin performansına bağlıdır. Kesin standartlara örnek olarak not değerlendirme sistemi verilebilir. Ancak normatif standartlar daha çok modelleri gözlemleme yoluyla elde edilir. Normatif standartlarda kişinin performansını, başarısı ile karşılaştırmak davranışın doğruluğunu değerlendirmede önemli bir yöntemdir. 1 saatte 2 sayfa metin yazma ödevini, akranlarına göre 30 dakika erken bitiren bir birey gibi.

Hedefin belirginlik, yakınlık ve zorluk özelliklerini içermesi önemlidir. Kendi hedefini kendi belirleyen öğrenci için hedefe kendini vermek daha kolay olabilir. Böylece birey hedefin öneminin de farkında olabilir.

Nitelikler, hedef geliştirme değerlendirmelerinin yanı sıra, öz yeterliliği, başarıyı, motivasyonu ve duygusal tepkileri etkileyebilir.

Tepki: Hedef gelişiminde tepki davranışı motive eder (Bandura, 1986; Zimmerman ve Schunk, s. 2004). Bireylerin performanslarının değerlendirmesine yönelik olan eğitim, motivasyonu artırır. Daha iyi yapacağını düşünen kişi daha uzun süre uğraşır ve daha fazla çaba sarf eder (Schunk, 2009, s. 121).

\section{Yazma Ĕgitimi}

İnsan yazı yazarken, duygu ve düşüncelerini belirli bir bilgi birikimi çerçevesinde aktarmaktadır. Vygotsky’e (1998, s. 145-146) göre yazı yazma, bilinçli bir çaba ile çocuğun 
bilerek çözümleyici bir eyleme girişmesini gerektirir. Bu bilinçli ve çözümleyici zihinsel çaba sebebiyle yazmada kullanılan zihin faaliyetleri, aynı zamanda "zihin yapısını düzenleyen işlemler" (Güneş, 2007, s. 160) olmaktadır.

Yazılı anlatım; bu açılardan bakıldığında kişinin bilgisi, konuyu kavrama düzeyi, sunmadaki düzeni, amacı ve konu hakkındaki fikirlerini yazıya dökmek için gerçekleştirdiği zihinsel faaliyettir. Gersten ve Baker (2001) bu konuda, iyi yazan öğrencilerin; gerekli sözel becerilere, düşünceyi organize etme becerisine, o anki düşüncelerini belli bir düzene göre yazma kabiliyetine, uygun bir bilgi altyapısına ve yazma sürecinde kendilerine rehberlik edecek kendini izleme stratejilerini kullanma yeteneğine sahip olmaları gerektiğini vurgulamışlardır. Ayrıca çocuğun yazma becerisi geliştikçe düşüncelerini düzenleme, bilgiyi transfer etme gibi beceriler de kendiliğinden gelişecektir. Bu becerilerin gelişmesinde kişinin kendini bilişsel, psikomotor ve duyuşsal açıdan düzenleme, neyi, ne zaman nasıl ve hangi sırada yapacağına karar verme ve bu kararlarını gerçekleştirebilme ihtiyacı öz düzenleme kavramını ortaya çıkarmaktadır. Öz düzenleme bireyin kendi davranışlarını gözleyip, kendi ölçütleriyle karşılaştırarak yargıda bulunması ve gerekiyorsa davranışlarını ölçütlere uygun hâle getirmesidir (Senemoğlu, 2009, s. 231). Öz düzenlemeye dayalı öğrenmenin yazma eğitimine uygulanmasıyla, birey yazma sürecinin aşamalarında zihnini kendi kendine düzenleyerek aktif bir öğrenme gerçekleştirebilir.

Bir dilde yeterli olma durumu, anlamaya ve anlatmaya dayalı temel dil becerilerinin kazanılmış olması ve etkin olarak kullanılabilmesini gerektirir. Temel dil becerilerinden biri olan yazma, ilköğretimin ilk yıllarından itibaren çocuklara kazandırılmaya çalış1lır. Karatay’a (2011, s. 21) göre, bu becerinin etkin kullanılabilmesi, bireyin dış dünyayı gözlemleme, sürekli okuma, düşünme ve yazma; kısacası hem anlama hem de anlatma becerilerinin yeteri kadar gelişmesine bağlıdır. Yazma becerisini geliştirmenin en önemli yolu, sürekli yazma çalışmaları yapmaktır.

Yazma çok karmaşık bir dil becerisidir. Bu karmaşık dil becerisini edinmek ve kullanmak için çocuğun örgün eğitime başladığı andan itibaren yazma becerisine karşı olumlu bir tutum göstermesi sağlanmalıdır. Bu olumlu tutum beraberinde yazmaya karşı öğrencide sempati oluşturacak ve öğrenci yazmaktan zevk duyduğu gibi yazılı anlatım kurallarını da yerine getirmekte zorluk çekmeyecektir. Ayrıca çocuğun yazma becerisi geliştikçe düşüncelerini düzenleme, bilgiyi transfer etme gibi beceriler de kendiliğinden gelişecektir. Akyol'a (2006, s. 93) göre de, çocuğun yazma becerileri geliştikçe bilgiyi transfer etme, 
düşünceleri gözden geçirip düzenleme daha etkili bir şekilde yapılır ve bu durum daha güzel yazılı ürünlerin ortaya çıkmasına imkân verir.

Yazma sürecinin sonunda başarılı bir ürün elde etmek için belirli aşamaları gerçekleştirmek gerekmektedir. Bu aşamalar hazırlık, yazma taslağı oluşturma, gözden geçirme, geliştirme-düzenleme, düzeltme ve yayımlama: paylaşma olarak sıralanabilir (Coşkun, 2007; Karatay, 2011). Bu yazma süreci kendi içerisinde çeşitli etkinliklerden, süreci doğru ve verimli işletmek için öğrencilerle birlikte çalışma aşamalarından oluşmaktadır (Karaalioğlu, 1978, s. 72; Şentürk, 2009, s. 21). Bu aşamalar;

1. Konunun seçilmesi / ortaya çıkması; konunun sınırlandırılması,

2. Konunun nasıl ele alınacağının tasarlanması; ana maddesinin belirlenmesi,

3. Konu hakkında söyleneceklerin bulunması,

4. Konu ile ilgili araştırmaların, gözlem ve deneylerin yapılması; iletinin belirlenmesi,

5. Yazılı anlatım planı yapılması; düşüncelerin anlamlı bir bütün oluşturacak şekilde yazilmas1,

6. Yazının değerlendirilmesi gibi karmaşık ve çaba gerektiren çeşitli süreçleri ve bir dizi çalışmaları kapsamaktadır.

Öğrencilerin bu aşamaların hepsine etkin olarak katılması durumunda; öğretmen ve öğrencilerin etkileşimine dayalı yazma çalışmaları için ortam oluşturulursa, yazılı anlatım becerileri daha hızlı bir gelişim gösterecektir (Karatay, 2011, s. 24). Yazma eğitiminin sorumluluğunu üstlenen, kendi yazma süreçlerini kontrol edebilen ve bu süreçlere aktif olarak katılan, kendi yeteneklerine güvenen ve bu yeteneklerini olumlu bir şekilde kullanan bireyler yetiştirmek gerekmektedir. Bu hedefe ulaşmada önemli unsurlardan biri de öz düzenlemeye dayalı öğrenmedir.

\section{Öz Düzenleme Becerisine Sahip Öğrencilerin Özellikleri}

Öz düzenleme becerisine sahip öğrenciler; belli bir öğrenme durumunun farkında olan, öğrenme sürecini verimli ve etkili geçirebilmek için en uygun öğrenme stratejisini seçebilen, bunların ne derece etkili olduğunu inceleyip öğrenme sürecini tamamlayana kadar güdülenmiş olarak işlem basamaklarını uygulayabilen öğrencilerdir. Derry ve Murphy’ye (1986'dan akt. Sağırlı ve Azapağası, 2009, s. 132) göre öz düzenleyici öğrenciler hedefi analiz etme ve 
tanımlama, stratejiyi planlama, stratejiyi uygulama, stratejinin sonuçlarını izleme ve stratejiyi uygun hâle getirme gibi beş basamaklı yaklaşımı benimseyen öğrencilerdir. Dolayısıyla öz düzenleyici öğrenciler, öz düzenlemeye dayalı öğrenmenin bilincinde olup bunu uygulayan bireylerdir.

Öz düzenleme becerileri yüksek bireylerin özellikleri şöyle sıralanabilir:

- Amaç belirleme yeteneği,

- Öğrenme ilgi ve yönelimi,

- Yüksek düzeyde öz yeterlilik,

- Konuya ilgi duyma,

- Kendi kendine öğrenmeye eğilim,

- Süreci gözlemleme,

- Öz değerlendirme,

- Etkenlere uyum sağlama yeteneği (Zimmerman'dan akt. William ve Hellman, 2004, s. 71-72).

Bu açıklamalara göre öz düzenlemeye dayalı öğrenmede (a) hedefe yönelik bir sürecin söz konusu olduğu, yani öğrencinin bir hedefinin olduğu, (b) öğrencinin bu hedefe ulaşmak için kendi inisiyatifi ile bağımsız olarak çalıştığı, yani sorumluluk aldığı, (c) gerek görevin gerekliliklerini belirleme, gerek kendi becerilerinin bu gereklilikleri karşılama düzeyi gerekse görevi tamamlamak için kullanabileceği stratejileri seçme bakımından üst bilişsel farkındalığa sahip olduğu, (ç) süreç boyunca çeşitli stratejileri kullanarak görevi tamamlamaya çalıştığı yani stratejik davrandığı, (d) yüksek düzeyde motive olduğu görülmektedir (Uyar, 2015, s. 47).

Yazma sürecinde, öz düzenleme becerisine sahip olan öğrencilerin kendi kendilerine şu soruları sorabilmeleri gerekir:

- Niçin yazmalıyım?

- Nasil yazmalıyım?

- Ne zaman yazmalıyım?

- Ne yazmalıyım? 
- Nerede yazmalıyım?

- Kimle veya kimlerle yazmalıyım?

$\mathrm{Bu}$ sorular, öğrencinin yazma sürecinde sorumluluk almasını, yazma ile ilgili planlar yapmasını ve birtakım kararlar almasını sağlar. Yazma sürecindeki öz düzenleme bireyin sorumluluk bilincinin gelişmesine, süreci kontrol edebilmesine, bağımsız çalışabilmesine katkıda bulunur. Öğrencilere bağımsızlık duygusunu hissettirdiği için onları yazmaya karşı güdüler. Bu zorlu süreçte çok sayıda öğrencinin birbiriyle etkileşimini sağlayabilir. Ayrıca üst bilişin gelişimine de zemin hazırlar.

\section{Öz Düzenlemeye Dayalı Öğrenmede Türkçe Öğretmeninin Rolü}

Öz düzenlemeye dayalı öğrenmenin yazma eğitimine uygulanması sürecinde en önemli rehber öğretmendir. Zira yazma stratejileri öğretmen tarafindan modellenir (Harris ve Graham, 1996).

$\mathrm{Bu}$ süreçte öğretmen, öğrencilere dönem ödevi veya proje verir. Ancak konuyu kendilerinin seçmelerini ister. $\mathrm{Bu}$ olmadığ Öğrenciler kullanacakları kaynakları, yazacakları konuyu, kendileri bağımsız bir biçimde seçerek öz yeterliliklerini ve öz hedeflerini gerçekleştirmek üzere adım atmış olurlar.

Bu süreçte öğretmenin amac1,

1. Yazdıklarını gözden geçirme, üretme ve planlamada öğrencilerin üst bilişsel teknikleri kullanıp kullanmadıklarını değerlendirmek,

2. Kendi yazma süreçlerinin yönetimine ve öz izleme yeteneklerinin gelişimine yardım etmek,

3. Yazmaya karşı olumlu tutum geliştirmektir.

Öz düzenlemeye dayalı öğrenmenin yazma eğitiminin uygulama sürecinde öğretmene düşen sorumluluklar ise şöyle sıralanabilir:

1. Her şeyden önce yazma çalışmaları öğretmen tarafından öğrenciye sevdirilmelidir.

2. Konu belirlemede birden fazla seçenek sunularak öğrencilerin özgürce seçim yapması sağlanmalıdır. 
3. Konu çerçevesinde kurdukları bağlam, kullandıkları dil ve anlatım kontrol edilmelidir.

4. Tekniklerin geliştirilmesi ile yazma sürecindeki akıcılığın gelişimi sağlanmalıdır.

5. Sadece yazma süreç ve tekniği değil yazının içeriği için de destek olunmalıdır.

6. Eğitim yazma sürecini destekleyecek bir ortamda gerçekleşmelidir.

7. Öğrenci yazıları okutulmalı, yazılar hakkında sorular sorulmalı ve öğrenci bu dönütler doğrultusunda kendi yazılarını düzenlemelidir.

8. Öğrencinin, arkadaşları ve öğretmenleri ile beraber çalışması sağlanmalıdır.

\section{Öz Düzenlemeye Dayalı Yazma Eğitiminde Aşamalar}

Öz düzenleme becerisi ile süreç odaklı yazma eğitimi iç içedir. Bu yazma eğitimine göre, iyi bir metnin ortaya çıkabilmesi için yazma sürecinde bazı bileşenler yer almalıdır. Bunlar:

Söz dizimi: Cümle yapısı, cümlelerin birbiriyle bağlantısı $v b$.

İçerik: Tutarlılık, açıklık, özgünlük $v b$.

Dil bilgisi: Özne-yüklem uyumu, çekimler $v b$. ile ilgili kurallar.

Metin düzeni: Paragraflar, bağıntı ve bağdaşıklık.

Kelime seçimi: Bağlama uygun kelime ve deyimler.

Amaç: Yazma amac1.

Hedef kitle: Okuyucular.

Yazma süreci: Yazma konusunu, düşünceleri belirlemek, yazıya başlamak, taslaklar oluşturmak, gözden geçirmek, geri bildirim almak $v b$.

Sürece dayalı yazma yaklaşımları, üst düzey öğrenmeye, düşünmeye, kendini kontrol etmeye, kendi kendine karar vermeye ve bilginin işlevsel olarak kullanılmasına odaklanmaktadır (Raimes 1983’ten akt. Karatay, 2011, s. 25-27). Yazma sürecinin planlanmasına ve her adımda önce öğretmenle daha sonra öğrencinin kendi kendini izlemesi ve değerlendirmesine ağırlık veren süreç odaklı yazma eğitimi, öz düzenlemeye dayalı öğrenmeyi de içine almaktadır. Yazma süreci için öz düzenlemeli strateji gelişimi yaklaşımı altı öğretici 
aşama sunmaktadır. $\mathrm{Bu}$ aşamalar öğretmene sunulan bir yazma öğretimi rehberi oluşturmaktadır. Öğretmenin ve öğrencinin ihtiyaçlarına göre bunların sıraları değiştirilebilir, birkaçı birleştirilebilir, bir aşamaya yeniden dönülebilir, gerek duyulmayan aşama atılabilir (Uzun, 2007).

1. Öğrencilerde art alan bilgisinin geliştirilmesi,

2. Kullanılacak öz düzenleme ve özelleşmiş yazma stratejilerinin tartışılması,

3. Öğretmenin rehberliğinde öğrenciler tarafından taslak oluşturulması ve taslağın birlikte gözden geçirilmesi,

4. Öğrenilen stratejilerin pekiştirilerek akılda tutulması,

5. Öğrencilerin, yazılarını öğrendikleri stratejileri kullanarak denetleyip yazma sürecinde birbirlerine destek vermeleri,

6. Öğrencilerin, öğretmenin desteği olmaksızın metin yazması.

Tablo 2: Öz Düzenlemeye Dayalı Yazma Eğitimi Basamakları

\begin{tabular}{|l|c|}
\hline 1. & Ön bilginin geliştirilmesi \\
\hline 2. & Tartışma \\
\hline 3. & Biçimlendirme \\
\hline 4. & Akılda tutma \\
\hline 5. & Destekleme \\
\hline 6. & Yazma Alışkanlığı Kazanma \\
\hline
\end{tabular}

(Harris ve Graham, 1996)

\section{Öz Düzenlemeye Dayalı Yazma Basamaklarına Göre Metin Oluşturma}

Bu alt bölümde öz düzenlemeye dayalı yazmanın aşamaları öyküleyici metin yazma örneğiyle gösterilmeye çalışılmıştır:

Öyküleyici metin, bir anlatıcının belli bir bakış açısı ile birbiriyle ilişkili olaylar dizisini belli bir zaman, mekân ve kurgusal bir düzen içinde sunması ile oluşmaktadır (Coşkun, 2007b). Öyküleyici metinde yazarın bilgi ve deneyimlerinden yararlanarak sınırlarını kendinin 
oluşturduğu kurgusal bir dünya vardır. Yazar, anlatımı sırasında okuyucunun tamamlamasını istediği bazı boşluklar bırakabilir. Okuyucu, ön bilgisi, deneyimleri ve kültürel düzeyine bağlı olarak metindeki boşlukları doldurmaya çalışır ve metnin henüz okumadığı bölümleri hakkında birtakım tahminlerde bulunur. Boşlukları doldurma çabası okurun düş gücünü kamçılar, onu pasif bir okuyucu olmaktan kurtarır (Günay, 2003, s. 204).

Öyküleyici metinlerin hepsinde bulunmamakla beraber genel olarak görebildiğimiz unsurlar dekor / mekân, kahramanların / karakterlerin tanıtılması, olay, problem (varsa), girişim, sonuç, (varsa) tepkidir (Coşkun, 2007b, s. 256).

Bu bilgiler göz önünde bulundurularak örnek uygulamada şöyle bir yol takip edilebilir:

\section{Basamak: Ön Bilginin Gelişstirilmesi}

Öğrencilerin hikâye ile ilgili bilgileri tartışmaya açılır. "Bir hikâyenin yazılması için gereken ögeler nelerdir?" sorusunun sınıfta tartışılması sağlanır. Bu tartışma sonrasında elde edilecek ya da hatırlanacak bilgilerle, ilgili yazma stratejilerinin ve hikâye şemasının temeli at1labilir.

Ardından birkaç hikâyenin sınıfta okunması ve tartışılması sağlanır. Böylece öğrencilerin hikâyede bulunması gereken şu üç temel ögeyi tanımlamasına yardımcı olunur: Kahramanların tanıtılması, problem, sonuç.

Daha sonra, onlardan okudukları yazılardan birinden esinlenerek kısa bir hikâye paragrafi oluşturmaları ve bu paragrafta kahramanları, problemi ve sonucu tanımlamaları istenebilir.

\section{Basamak: Tartışma}

Ayşe'nin yeni evinde başından geçen olayları anlatan bir hikâye yazınız.

$\mathrm{Bu}$ aşamada öğrencilerle beraber yazıda kullanılacak stratejilerin düzenlenmesi ve tartışılması gerçekleştirilir. Öncelikle konu ile ilgili bir resim gösterilir. Resimde geçen kavramların tanımlanması istenir. Ardından şu soru ve yönergeler doğrultusunda öğrencilerin öz düzenleme yapması sağlanır:

- Resimde kaç kişi görüyorsunuz? Sizce Ayşe hangisi olabilir?

- Ana karakter (Ayşe) ve ana karakterin yanındakilerin özelliklerini fiziksel ve ruhsal açıdan tanımlayınız. 
- Olay ne zaman ve nerede (dekor) geçmektedir?

- Ayşe neler yapmak istiyor ve bunu etkileyen diğer karakterlerin davranışları nelerdir?

- Öteki karakterlerle Ayşe'nin ilişkileri nasıldır?

- Olayların akışı ne şekildedir?

- Hikâye nasıl sona eriyor?

- Kahramanların tanitılması

- Başlatıcı olay

- Problem (çatışma)

- Girişim (kahramanın hedefi)

- Sonuç

- Tepki (Herhangi bir bölümde de olabilir.)

Bütün bu sorular yöneltildikten sonra öğrencilerden cevapları doğrultusunda hikâyelerini planlayıp yazmaları istenir.

\section{Basamak: Biçimlendirme}

$\mathrm{Bu}$ aşamada öğrenciler hikâyelerinin ilk taslağını yazmaları için motive edilirler. Yazma sürecinde öğrencilerin öz düzenleme becerisini kullanmaları sağlanır. Bu amaçla, onların başlatıcı olay tanımı yapmasını (Olay nasıl başlayabilir?), planlama yapmasını (Öncelikle şu ögeyi belirlemem gerekiyor...), kendilerini değerlendirmesini (Ben hangi basamaktayım, daha fazla hangi ayrıntılardan bahsedebilirim, yazdıklarımı doğru bir biçimde gerçekleştirebiliyor muyum? Söylediğime gerçekten inanıyor muyum?) ve kendi kendini ödüllendirmesini (Çok güzel, bu gerçekten güzel bir olay!) sağlayacak yönlendirmeler yapılmalıdır. Yazıların ilk biçimi okunduktan sonra gerekli düzeltmeler yapılır.

\section{Basamak: Akılda tutma}

Öğrencilerin, öz düzenleme becerilerinin kalıcı olmasını sağlayacak çalışmalar yapılmalıdır. Öğrencilerin öğrenme sürecinde yaşantılarını akılda tutma sorunlarının olduğu unutulmamalıdır. Öğrencilerin hikâye ile ilgili bilgileri hatırlamalarını sağlayacak etkinlikler yapılmalıdır.

$\mathrm{Bu}$ aşamada şöyle bir yol izlenebilir: 
1. Öğrenciler yazdıkları hikâyenin unsurlarını ve oralarda neler yazdıklarını listeleyebilirler.

2. Resimde gördüklerini tekrar tanımlamaları istenebilir (Ana karakter Ayşe, Ayşe uzun sarı saçlı, minik, tatlı bir kız vb.).

3. Bir hikâyede bulunması gereken unsurların neler olduğu sorulabilir.

4. Onlara grup içi yarışmalar veya ikili çalışmalar yaptırılarak birbirlerini değerlendirmeleri sağlanabilir.

$\mathrm{Bu}$ aşama öğrenciden öğrenciye farklılık gösterebilir. Bazı öğrenciler bilgileri hemen hatırlarken, bazı öğrenciler bilgileri hatırlamakta zorlanacaklardır.

\section{Basamak: Destekleme}

$\mathrm{Bu}$ aşamada öğrenciler öğretmenden veya arkadaşlarından yardım alarak yazma yaşantıları geçirmeye devam edebilir.

1. Yazdıkları yazıları tekrar gözden geçirerek yeniden oluşturmaları için arkadaşlarından veya başkalarından yardım alması sağlanabilir.

2. Yazar veya öğrenci kendi kendini izlemeyi gerçekleştirebilir.

3. Küçük bir grupla veya arkadaşı ile yazdığı metni gözden geçirebilir

4. Öğretmen bu adıma kadar yapılanları kısaca anlatabilir.

Destekleme sürecinde önemli olan, öğrendiklerini yazma ve öz düzenleme stratejilerini kullanarak başka hikâye yazıları oluşturmalarıdır. Önceleri kısa yazılan hikâyeler gittikçe hacim kazanmaya başlayabilir.

\section{Basamak: Yazma Alışkanlığı Kazanma}

Bu aşamada öğrencilerin artık öğretmen yardımı olmadan hikâye unsurlarını planlama, bunları anlamlı ve tutarlı bir biçimde bir araya getirerek öyküleyici metin yazma becerisi kazanmış olmaları beklenir. 


\section{Sonuç}

Yazılı anlatım, bireyin kendini doğru ve amacına uygun olarak ifade etmesinde ve iletişim kurmasında en etkili araçlardan biridir. Türkçe Öğretim Programı'nda yazma becerisinin geliştirilmesiyle; öğrencilerin duygu, düşünce, hayal, tasarı ve izlenimlerini dilin imkânlarından yararlanarak ve yazılı anlatım kurallarına uygun şekilde anlatmaları, yazmayı kendini ifade etmede bir alışkanlığa dönüştürmeleri ve yazma yeteneği olanların bu becerilerini geliştirmeleri amaçlanmaktadır. Uzun bir süreç isteyen yazma becerisinin kazanılması ve istenen amaçlara ulaşılması, ancak çeşitli ve özendirici yazma uygulamalarıyla mümkün olur (MEB, 2006, s. 7).

Not alma, özet çıkarma, boşluk doldurma, kelime ve kavram havuzundan seçerek yazma, serbest yazma, kontrollü yazma, güdümlü yazma, yaratıcı yazma, metin tamamlama, tahminde bulunma, bir metni kendi kelimeleriyle yeniden oluşturma, bir metinden hareketle yeni bir metin oluşturma, duyulardan hareketle yazma, grup olarak yazma ve eleştirel yazma şeklinde programda yöntem ve teknikler yer almaktadır. Bu yöntem ve teknikler öz düzenlemeye dayalı öğrenmenin yazma eğitimi aşamalarında kullanılabilir. Özellikle "Bir metni kendi kelimeleriyle yeniden oluşturma, bir metinden hareketle yeni bir metin oluşturma, duyulardan hareketle yazma, grup olarak yazma ve eleştirel yazma" yöntem ve tekniklerini 6 . basamakta (Yazma Alışkanlığı Kazanma) kullanabilirler. Örneğin, öz düzenlemeli yazma eğitiminin 1. basamağı için ön bilgilerinin geliştirilmesinde birey not alarak yazmayı kullanabilir. Ayrıca 2. basamakta yazma stratejisi geliştirirken kelime ve kavram havuzundan seçerek yazma ile güdümlü yazmayı kullanabilir.

Ayrıca programın ölçme ve değerlendirme bölümünde;

Öğrencilerin kendi çalışmaları hakkında kararlar vermesidir. Öz değerlendirme uygulamaları ile öğrencilere çalışmaları hakkında dönütler verilmekte, eleştiri yapma becerisi kazanmalarına yardımcı olunmaktadır. Türkçe dersinde, öğrencilerin kendilerini değerlendirmesi amacıyla, çeşitli öz değerlendirme formları kullanılabilir. Bunlar kontrol listeleri, açık uçlu sorular ve dereceli puanlama anahtarları olabilir. Türkçe dersinde öğrencilerden öz değerlendirme sırasında istenen; katıldıkları etkinliklere, işlenen metin ve temalara, performans ödevlerine ilişkin kendilerine soru sorarak güçlü ve zayıf yönlerini belirlemeleridir (MEB, 2006,s. 220). 
denilerek öz düzenlemenin tanımı ve açıklaması yapılmakta, öz değerlendirme basamağına ait ölçeklere yer verilmektedir. $\mathrm{Bu}$ da öz düzenlemeye dayalı öğrenmeye Türkçe Öğretim Programı'nda bir hayli önem verildiğinin delili sayılabilir.

\section{Kaynaklar}

Aydın, S ve Atalay Demir,T. (2015). Öz-düzenlemeli öğrenme. Ankara: Pegem A Yayıncılık.

Beyreli L., Çetindağ Z. ve Celepoğlu A. (2005). Yazılı ve sözlü anlatım. Ankara: Pegem A Yayınc1lik.

Coşkun, E. (2005). İlköğretim öğrencilerinin öyküleyici anlatımlarında bağdaşıklık, tutarlılık ve metin elementleri. Yayımlanmamış Doktora Tezi, Ankara: Gazi Üniversitesi Eğitim Bilimleri Enstitüsü.

Coşkun, E. (2007-a). Yazma eğitimi. (ed. Ahmet Kırkkılıç ve Hayati Akyol). İlköğretimde Türkçe Öğretimi. Ankara: Pegem Akademi Yayınc1lık, 49-91.

Coşkun, E. (2009-b). Türkçe öğretiminde metin bilgisi. (ed. Ahmet Kırkkılıç ve Hayati Akyol). İlköğretimde Türkçe Öğretimi. Ankara: Pegem Akademi Yayıncılık. 233-279.

Espin, C. A., Weissenburger, J. W. ve Benson, B. J. (2004). "Assessing the Writing Performance of Students in Special Education", Exceptionality, 12, 55-66.

Gersten, R. ve Baker, S. (2001). Teaching expressive writing to students with learning disabilities: A meta-analysis. The Elementary School Journal, 101(3), 251-272.

Günay, D. V. (2003). Metin Bilgisi. İstanbul: Multilingual Yayınları.

Güneş, F. (2007). Türkçe öğretimi ve zihinsel yapılandırma. Ankara: Nobel Yayın.

Güvenç, H. (2010). İş birlikli öğrenme ve ders günlüklerinin öğretmen adayı öğrencilerin öz düzenlemeli öğrenmeleri üzerinde etkileri. Kuram ve Uygulamada Eğitim Bilimleri, 10(3), 1459-1487.

Harris, K. R. ve S. Graham. (1996). Making the writing process work: Strategies for composition and self-regulation. Cambridge, MA: Brookline Books.

Harris, K. R., Graham S., Mason L. ve Saddler B. (2002). Developing self-Regulated writers. Theory in to Practice, 41, 110-115.

http://www.tdk.gov.tr

İsrael E. (2007). Öz düzenleme eğitimi, fen başarısı ve öz yeterlilik. Yayımlanmamış Doktora Tezi, İzmir: Dokuz Eylül Üniversitesi, Eğitim Bilimleri Enstitüsü.

Karaalioğlu, S. K. (1978). Sözlü yazılı kompozisyon konuşmak ve yazmak sanatı. İstanbul: İnk1lap Kitabevi.

Karatay, H. (2011). Süreç temelli yazma modelleri: planlı yazma ve değerlendirme. (ed. Murat Özbay). Yazma eğitimi. Ankara: Pegem Akademi Yayınc1lık. 21-43. 
MEB. (2006). İlköğretim Türkçe dersi (6.,7. ve 8. sinıflar) ögretim programı. Ankara: Millî Eğitim Bakanlığ 1 .

Özbay, M. (2002). Yazılı anlatım becerisinin geliştirilmesi. Sadık Tural Armağanı. Ankara: Can Reklamevi Basın Yayın.

Pajares, F. (1996). Self-efficacy beliefs in academic settings. Review of Educational Research, 66(4), 543-578.

Pintrich, P. R. (2004). A conceptual framework for assessing motivation and self-regulated learning in college students. Educational Psychology Review, 16(4), 385-407.

Sağırlı Özturan M. ve Azapağası E. (2009). Üniversite öğrencilerinin öğrenmede özdüzenlemeyi öğrenme becerilerinin incelenmesi. Ankara Üniversitesi Eğitim Bilimleri Fakültesi Dergisi, 42(2), 129-161.

Schunk, D. H. (2009). Öğrenme teorileri-eğitimsel bir baklşla. (çev. ed. Muzaffer Şahin), Ankara: Nobel Yayın Dağıtım.

Senemoğlu, N. (2009). Gelişim, öğrenme ve öğretme. Ankara: PegemA Yayıncılık.

Şentürk, N. (2009). Planlı yazma ve değerlendirme modelinin 8. sinıf öğrencilerinin bilgilendirici metin yazma becerilerini geliştirmeye etkisi. Yayımlanmamış Yüksek Lisans Tezi, Bolu: Abant İzzet Baysal Üniversitesi, Sosyal Bilimler Enstitüsü.

Tiryaki, E. N. (2011). Öz düzenlemeye dayalı öğrenme ve Türkçe ögretiminde yazma eğitimine uygulanması. Gazi Üniversitesi Eğitim Bilimleri Enstitüsü Türkçe Eğitimi Ana Bilim Dalı Türkçe Öğretiminde Yeni Strateji ve Teknikler Dersi Seminer Notları.

Uyar, Y. (2015). Öz düzenlemeye dayall okuma becerisinin geliştirilmesi ve anlamaya etkisi. Yayımlanmamış Doktora Tezi, Ankara: Gazi Üniversitesi Eğitim Bilimleri Enstitüsü Türkçe Eğitimi Ana Bilim Dalı.

Uzun, L. (2007). Öz düzenleme yapabilen her öğrenci yazabilir. http://modersmal.skolutveckling.se/turkiska (Erişim Tarihi: 11.04. 2011).

Vygotsky, L. S. (1998). Düşünce ve dil. (çev. Semih Koray). İstanbul: Toplumsal Dönüşüm Yayınları.

Zimmerman, B. J. (2000). Attaining self regulation: A social cognitive perspective. In P. Boekaerts, R. Pintrich, ve M. Zeidner (eds.). Handbook of self-regulation. London, UK: Academic Press. 